\title{
INCREASING THE IMPACTS OF INFORMATION TECHNOLOGY USAGE ON BUSINESS VALUE
}

\author{
Agus Prayitno* \\ Universitas Dian Nuswantoro
}

\begin{abstract}
The purpose of this study is to examine a conceptual model of the relationship between the use of information technology, information technology strategy, and information technology business value and to formulate strategic priorities to increase the business value of information technology. The data of this research were the perceptions of 126 executives of large manufacturing companies in Central Java about indicators of information technology use, information technology strategy, and information technology business value. The analysis used descriptive and explanatory methods with multiple linear regression to explain the causal relationship of the variables of information technology usage, information technology strategy, and information technology business value. The results show that the use of information technology and information technology strategies has a positive effect on business value. Surprisingly, the information technology strategy was proved to be a moderating variable and was able to increase the effect of information technology usage on business value.
\end{abstract}

Keywords: Information technology usage; Information technology strategy; Information technology business value.

Received: 11 August 2018

Accepted: 20 May 2020

\section{INTRODUCTION}

The phenomenon of companies engineering business processes with the support of information technology (IT) to increase business value is still a very interesting study for researchers (Daulatkar \& Sangle, 2015; Kossai \& Pigget, 2014). Various business value variables and methods have been used to measure the business value of IT: profitability (Jiang \& Zhao, 2014; Kossai \& Pigget, 2014), firm performance (Luftman et al., 2017; Chen et al., 2017; Choy et al., 2014), productivity (Ogutu et al., 2014; Kite, 2012; Kleis, 2012; Lee et al., 2011), and business value (Daulatkar \& Sangle, 2015; Bardhan et al., 2013).

The application of IT is implemented by formulating the objectives of using IT. There are three categories of purposes for the use of information technology, namely: supporting transactional activities (Schermann, et al., 2016; Alaghehband et al., 2011), supporting informational categories (Dimitrios et al., 2013; Kim \& Chai, 2017), and supporting decision making (Boulesnane \& Bouzidi, 2013). Transactional activities mean the purpose of implementing information technology

\footnotetext{
- Corresponding author:Faculty of Economics and Business, Dian Nuswantoro University Semarang, Indonesia, 50131, Email : agus.prayitno@dsn.dinus.ac.id.
} 
to support routine organizational processes; Informational categories mean the application of information technology to support communication between parts of the organization; and decision making means information technology used to support strategic decision making.

Besides setting the goal of using IT, creating a strategy to achieve these goals is very important in determining the business value of IT (Tallon et al., 2000). The use of information technology strategies includes planning, controlling, and evaluating the application of IT.

Most of the previous studies examined the effect of information technology based on the quality of information systems (Petter, et al., 2013; Gorla, et al., 2010), and the alignment of IT and business (Suh, et al., 2010; Telbany \& Elragal, 2014). But there is still little study of IT strategies which can strengthen or weaken the influence of IT use on organizational performance. This research focuses on IT strategy as a moderating variable in increasing the influence of IT on business value.

Based on the description above, it is necessary to study comprehensively from various aspects of business value how the interaction of use and strategy of information technology can provide added value influence of the use of IT on business value.

\section{LITERATURE REVIEW}

\subsection{IT Business Value}

Business value of information technology is an organizational performance resulting from the application of information technology at the process and organizational levels which include the influence of efficiency and competitiveness (Melville et al., 2004). At the process level the value of information technology business includes the influence of information technology on business activities in company's value chain system (Tallon et al., 2000; Jiang \& Zhao, 2014; Mendonca, 2003) and the business value of technology which is reflected in all business processes in the operational process and management process, including inbound logistics activities, company operations that transform raw materials into finished goods, outbound logistics, marketing and sales, and service activities.

The construct of business value of information technology is measured by performance indicators as used by Tallon et al. (2000) namely:

1) Effectiveness

Information technology increases organizational effectiveness (Zhang et al., 2004). Amado and Walczuch (2012) conclude that IT capabilities facilitate the formulation of strategies and mediate the influence of IT on company performance.

2) Supplier relations

Operational integration with suppliers is needed so that information exchange becomes very important. The use of information technology improves integration with suppliers (Vanpoucke et al., 2017). Information technology improves relationships with suppliers by reducing 
ordering costs, ordering waiting times, and improving quality monitoring and supplier services (Grover et al., 2002).

3) Production and operation

Information technology increases productivity by reducing the cost of designing new products, increasing output levels, reducing production costs (Lee et al., 2011). Integrated IS capabilities, as well as complementary effects of IS capabilities with manufacturing, marketing and supply chain processes, are significant predictors of manufacturing performance (Bharadwaj, 2000).

4) Products or services

Information technology enhances products and services by increasing new product innovations (Cui el al., 2015). Application of information system technology has a significantly positive impact on business performance through product innovation capabilities (Hamdani \& Susilawati, 2018).

5) Sales and marketing

Information technology enhances market support by helping to identify market developments, providing new market segments, increasing the accuracy of sales forecasting, providing market response information from promotions, and providing information on price policy responses (Trainor et al., 2011). Better IT infrastructure capabilities improve dynamic marketing capabilities (Wang et al., 2013).

6) Consumer relations

IT improves coordination between buyers and suppliers by increasing the flow and accuracy of information (Bhatt \& Emdad, 2010). Firm's IT infrastructure capabilities are positively associated with its IT support for CRM (Wang et al., 2013).

\subsection{IT Usage}

The use of information technology is an information technology application in the operational activities and strategic activities of an organization. The purpose of using information technology includes the applications of cost reduction, management support, strategic planning, and competitiveness. Companies can choose partially or in combination between increasing the support of the company's transactional processes, supporting information dissemination, improving internal or inter-company communication capabilities and providing decision-making support in company management.

The construct of the use of IT is developed by combining more concrete measures, namely information technology applications that are used. The indicators used to develop the construct of the use of information technology are:

1) Transactional system. This system is used to support business processes by automating business transactions (Schermann et al., 2016; Alaghehband et al., 2011).

2) Informational system. This system is used to provide reports to support management activities in carrying out corporate control. Indications of the use of this informational system include generating information in accordance with the required levels of management and functional organization (Dimitrios, 2013; Kim \& Chai, 2017). 
3) Communication system. This system provides facilities for communicating between parts within the company as well as with parties outside the company such as suppliers or consumers. Communication systems include intranets and the internet (Bhatt \& Emdad, 2010).

4) Decision support system. This system provides information intended for decision makers. Indications of the use of decision support systems include the system which provides information relevant to the decisions to be taken, and the system which is able to provide information about alternative strategic solutions (Boulesnane \& Bouzidi, 2013).

\subsection{IT Strategy}

Information technology strategy is an action in implementing information technology to achieve harmony between business strategies and information technology strategies (Smaczny, 2001). The company makes an effort to integrate IT strategies with business strategies through the following steps:

1) Formulation of an IT strategy framework. Corporate strategies that are supported by appropriate information technology strategies will be more directed and effective at creating strategic advantages through information technology. This strategy framework includes the determination of corporate strategy needs, the need for functional strategies and information technology unit strategies.

2) External IT exploration. The company will be able to take advantage of the opportunity to innovate with the right information technology applications to support the overall organizational process.

3) Internal IT identification. The company identifies the basic strengths and weaknesses of internal information technology. Through this activity the company can determine priorities in developing information technology.

4) IT implementation program. Organizations that have a clear IT program will facilitate operational implementation of the use of information technology.

5) IT budget. The budget set from the beginning shows the existence of priorities and interests and organizational commitment in using information technology.

6) IT service area level. When information technology business area is on the same level as other business areas such as finance, marketing and so on, then the IT unit has strong bargaining in applying information technology.

7) The level of IT managers. Information resource managers as top level management will be involved in developing the company's strategic plan, so that the direction of the information technology strategy will be in accordance with the business strategy.

8) Involvement of IT strategies. Strategic planning involves information resources, both business strategies and information technology strategies to be mutually supportive and integrated.

9) IT executive communication. When IT executives and business executives communicate intensively, the information technology built will suit business needs.

\subsection{The Relationship between The Various Variables}

\subsubsection{IT usage and IT business value}

Indicators of the use of information technology include information technology applications in improving the ease of transaction processing (transactional systems), the ability to provide 
information for management processes (informational systems), communication skills within and between organizations (communication systems), and the ability to support decisions (decision support systems). Transactional systems automate company business transactions. Information technology support in handling transactions within the company will result in reduced labor use, increased reliability, increased accuracy due to increased productivity, reduced labor, and reduced costs (Mooney, 1996).

The use of information technology influences the efficiency of the production process (Shao \& Lin, 2001). Informational systems provide services by collecting, storing, processing and disseminating information for management functions such as organizational planning and control. Using useful, contemporary, flexible, and qualified information will increase organizational effectiveness which consequently will increase the IT business value. The communication system provides communication facilities between parts within the company and with outside parties such as suppliers or consumers. Through this system organizational coordination is more effective, improves the quality of supplier and consumer relations, and facilitates the integration of internal and external processes.

Decision support systems provide reports for consideration in making a decision. Proper information support will improve the quality of decisions in the process of innovation and transformation, improve the ability to compete and develop markets. A better decision support system will increase IT business value.

Hypothesis1: The use of information technology has a positive influence on IT business value

\subsubsection{IT Strategy and IT business value}

Alreemy et al., (2016) stated the reason for the need to adjust the formulation of business strategies with information system strategies: (1) Technology does not provide a competitive advantage on its own, but needs integration with organizational processes and structures to achieve excellence; (2) Information technology enables enough influence as a driver to change organizations, processes, products and markets; (3) although information technology is a transformation tool, its technicality and effectiveness are still a problem in the business area. The influence of the use of IT on business value is highly dependent on the quality of the IT strategy (Yeh et al., 2012). In a high level of suitability between business strategies and information technology strategies, information technology will be more appropriate in supporting business processes. The level of suitability of this strategy will affect the quality of information technology support for operational processes and management processes which ultimately increase the business value of information technology.

Hypothesis2: Information technology strategies have a positive influence on the business value of information technology.

\subsubsection{IT usage, IT strategies and IT business value}

Mandal and Bagchi (2016) prove that information management strategies and technology management strategies determine company performance. IT strategies will strengthen or weaken the influence of IT use on IT business value. The interaction of IT strategies and the use of IT 
influences the business value of IT, and the IT strategy as a moderating variable influences the use of IT on the business value of IT.

Figure 1: Model of The Relationship Among IT Usage, IT Strategies, and IT Business Value

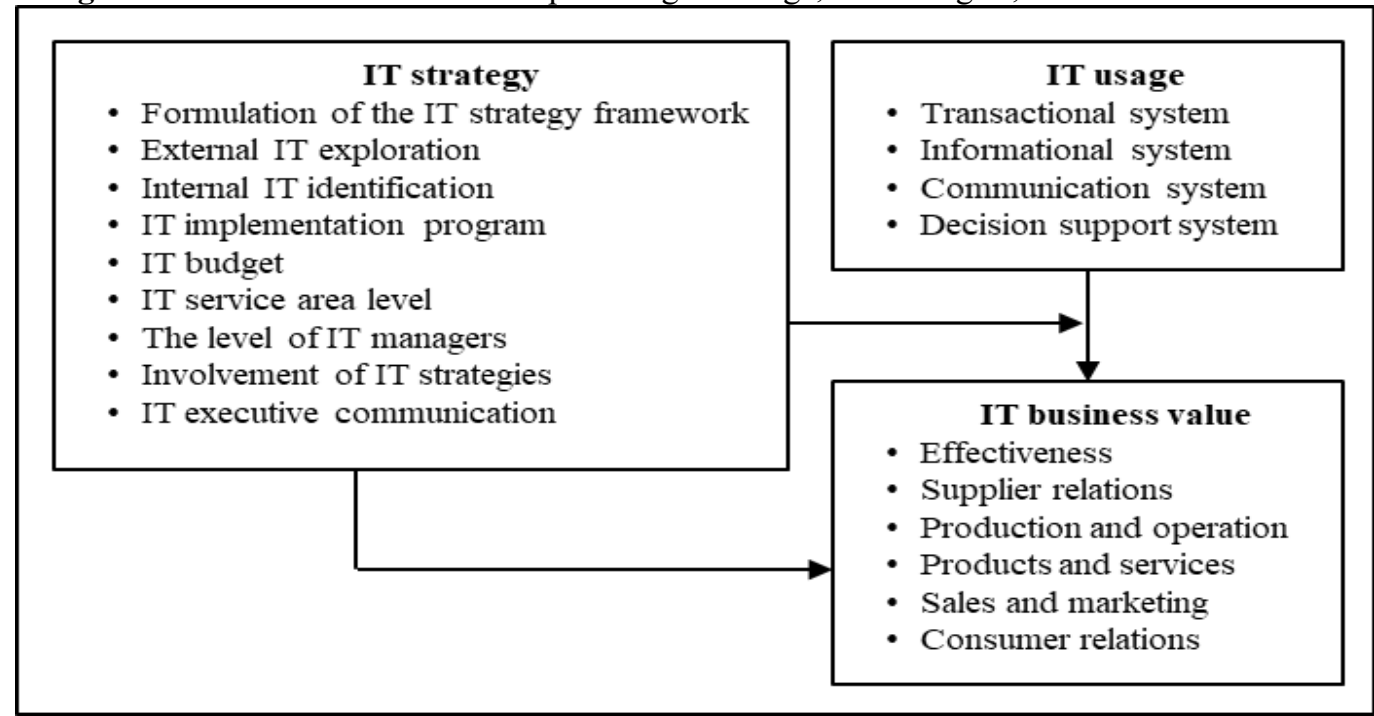

Higher intensity of IT strategy will increase the influence of IT usage on IT business value. The use of IT coupled with the formulation of an IT strategy framework, external IT exploration, internal IT identification, the implementation of IT programs, IT budget security, capable IT service areas, IT manager level with other business managers and IT strategies involved and IT executive communication established with other executives will increase the impact of using IT on business value.

Hypothesis 3: IT strategy moderates the effect of IT use on IT business value.

\section{METHODOLOGY}

The population of this research includes 708 large manufacturing companies in Central Java, Indonesia, namely companies which has a workforce of more than 100 workers and which utilize information technology in their business activities. The reason for using a manufacturing company is for the sake of being able to describe a more complete business process about the impact of using IT. Data were collected through questionnaires via e-mail to all members of the population. Research respondents were company executives. There were 126 of 137 returned questionnaires which were filled in completely.

The type of data is qualitative, namely the perceptions that respondents feel about indicators of use, strategy and business value of IT. Using a Likert scale of 1 to $7(1=$ very low to $7=$ very high), the method is closer to continuous and reduces bias. The analysis technique uses multiple linear 
regression analysis with the business value of IT as the dependent variable, the use of IT as independent variable, and IT strategy as an independent variable as well as a moderating variable.

\section{RESULT AND DISCUSSION}

\subsection{Description of Respondents' Perceptions of IT Usage Variables}

Table 1: Respondents' Perceptions of IT Usage

\begin{tabular}{lc}
\hline \multicolumn{1}{c}{ Indicator } & Average \\
\hline Transactional system & 5.02 \\
Informational system & 4.68 \\
Communication system & 4.44 \\
Decision support system & 3.13 \\
\hline Total average & $\mathbf{4 . 3 2}$ \\
\hline \hline
\end{tabular}

Table 1 shows that the average of respondent's perception of IT use is sufficient. The application of the transactional system is perceived to be the highest, while the application of the decision support system is perceived as the lowest. Between these are company's use of IT at the level of transaction, information, and communication.

\subsection{Description of Respondents' Perceptions of IT Strategy}

Table 2 shows that the average of respondents' perceptions of the company's IT strategy is quite low. All IT strategy indicators are also considered low. The company does not have a clear IT strategy. The use of IT is not accompanied by an adequate strategy.

Table 2: Respondents' Perceptions of IT Strategy

\begin{tabular}{|c|c|}
\hline Indicator & Average \\
\hline IT strategy framework formulation & 3.22 \\
\hline External IT exploration & 3.23 \\
\hline Internal IT identification & 3.08 \\
\hline IT implementation program & 3.19 \\
\hline IT budget & 2.95 \\
\hline IT service area level & 3.50 \\
\hline IT manager level & 3.28 \\
\hline Involvement of IT strategies & 3.11 \\
\hline IT executive communication & 2.90 \\
\hline Total average & 3.16 \\
\hline
\end{tabular}

\subsection{Description of Respondents' Assessment of IT Business Value Variables}

Table 3 shows that the average of respondent's perception of the business value of IT is sufficient. The highest IT business value perceived by respondents is product development, while consumer 
relations are perceived as the lowest. This phenomenon shows that IT applied is more supportive in product development. This is reasonable because the object of research is a manufacturing company.

Table 3: Respondents' Perceptions of IT Business Value

\begin{tabular}{lcc}
\hline \hline & Indicator & Average \\
\hline Effectiveness & & 3.88 \\
Supplier relationship & 4.12 \\
Production and operation & 4.34 \\
Products & 4.43 \\
Sales and marketing & 3.98 \\
Consumer relations & 3.67 \\
\hline Total average & $\mathbf{4 . 0 6}$ \\
\hline \hline
\end{tabular}

\subsection{Validity and Reliability}

Table 4: Results Test for Validity and Reliability

\begin{tabular}{lcc}
\hline \hline \multicolumn{1}{c}{ Indicator } & Corrected item-total correlation & $\begin{array}{c}\text { Cronbach's alpha if item } \\
\text { deleted }\end{array}$ \\
\hline Transactional system & 0.730 & 0.891 \\
Informational system & 0.839 & 0.852 \\
Communication system & 0.794 & 0.870 \\
Decision support system & 0.766 & 0.879 \\
IT strategy framework formulation & 0.774 & 0.950 \\
External IT exploration & 0.814 & 0.948 \\
Internal IT identification & 0.792 & 0,949 \\
IT implementation program & 0.835 & 0.947 \\
IT budget & 0.871 & 0.945 \\
IT service area level & 0.825 & 0.947 \\
IT manager level & 0.819 & 0.948 \\
Involvement of IT strategy & 0.803 & 0.949 \\
IT executive communication & 0.784 & 0.950 \\
Effectiveness & 0.880 & 0.949 \\
Supplier relationship & 0.820 & 0.955 \\
Production and operation & 0.896 & 0.947 \\
Products & 0.851 & 0.952 \\
Sales and marketing & 0.881 & 0.949 \\
Consumer relations & 0.888 & 0.948 \\
\hline \hline
\end{tabular}

Table 4 shows that all item-total correlations are greater than 0.50 and Cronbach's alpha values are greater than 0.70 , so that all indicators are valid and reliable. 


\subsection{Regression Equation and Hypothesis Testing}

Table 5: Regression Coefficients

\begin{tabular}{ccccccc}
\hline \hline \multirow{2}{*}{ Model } & \multicolumn{2}{c}{ Unstand. Coefficients } & Stand.Coefficients & \multirow{2}{*}{ t } & \multirow{2}{*}{ Sig. } \\
\cline { 2 - 5 } & B & Std. Error & Beta & & \\
\hline (Constant) & 1.605 & 1.736 & & 0.924 & $\mathrm{n} / \mathrm{s}$ \\
IT usage & 0.302 & 0.126 & 0.317 & 3.973 & $* * *$ \\
IT strategy & 0.414 & 0.071 & 0.507 & 5.833 & $* * *$ \\
Interaction of the IT usage \& IT strategy & 0.505 & 0.004 & 0.583 & 2.315 & $* *$ \\
\hline \hline
\end{tabular}

Notes :

dependent Variable: IT business value; $\mathrm{n} / \mathrm{s}$ : not significant ; ${ }^{* *} \mathrm{p}<0.001 ; * * \mathrm{p}<0.05$

Regression equation:

IT business value $=1,605+0.302 *$ IT_usage $+0.414 *$ IT_strategy $+0.505 *$

$$
\text { IT_usage*IT_strategy }
$$

Based on Table 5, the effect of IT use on business value of IT is significant $(B=0.302, p<0.001)$, so it can be concluded that the more intensive the company uses IT, the more business value will increase. Hypothesis $\mathbf{1}$ is accepted. Apart from that, IT strategy is positively associated with IT business value. The influence of IT strategy on IT business value is significant $(B=0.414, p=$ $0,001)$. Increasing the intensity of IT strategies is more effective in increasing business value. Hypothesis 2 is accepted. The influence of the interaction of information technology strategy with the use of information technology is significant $(B=0.505, p=0,05)$. The interaction of IT usage and IT strategy has a positive influence on the value of IT business. It can be concluded that the IT strategy moderates the effect of IT use on IT business value. Hypothesis 3 is accepted.

\subsection{Discussion}

\section{IT usage and IT business value}

The use of IT has a positive influence on IT business value. The higher intensity of IT use which includes transactional, informational, communication, and decision making systems will increase IT business value. More IT applications used in transaction automation such as purchase transactions, sales, employee attendance, use of raw materials, and products, will increase executive perception of IT business value. These results support the research of Aubert and Rivard (2016) that IT supports business processes by automating business transactions. More and more IT applications are used to produce reports or information to support management tasks such as inventory monitoring, monitoring product quality, will increase executive perceptions of IT business value (Dimitrios, 2013; Kim \& Chai, 2017). More use of IT that facilitates communication between parts within companies such as intranets, and communication networks will increase the value of IT business (Bhatt \& Emdad, 2010). More use of IT to support decisions will increase the business value of IT. Decision support systems provide reports that are intended for consideration in making a decision. Proper information support will improve the quality of decisions in the 
process of innovation and transformation, improve the ability to compete, and develop markets. A better decision support system will increase business value (Boulesnane \& Bouzidi, 2013).

Table 4 shows that the informational system has the largest item-total correlation, while the transactional system has the smallest item-total correlation. Large manufacturing companies in Central Java are currently in the informational era after experiencing the transactional era. The informational system has the highest contribution and the company has also implemented it quite high, as evidenced by the perception of respondents (Table 1) relatively high. Transactional systems contribute lower than other attributes, even though the average value for transactional given by respondents is quite high. Communication systems and decision support systems have a greater contribution than transactional systems, although the average value given by respondents to both attributes is lower. Although in reality the communication systems and decision support systems developed were still low, they contributed more to the use of IT.

\section{IT Strategy and IT business value}

The results of the study proves that the IT strategy has a significant influence on increasing the business value of IT. Although executives assess IT strategies are lower than the use of IT, the influence of IT strategies on business value is higher than the influence of IT use. These results indicate that increasing the intensity of IT strategies is more effective in increasing business value. Improving the IT strategy means formulating a better IT strategy framework, exploring external IT more precisely, identifying internal IT more precisely, developing a more planned IT implementation program, budgeting more continuously, forming more independent IT service areas, placing IT leaders at a higher level, and improving the communication of IT managers with other managers. The results of this study support Mandal and Bagchi (2016) stating that IT strategy determines company performance, and Yeh et al. (2012) stating that the influence of the use of IT on business value is very dependent on the quality of IT strategy.

Respondents' perceptions of the IT strategy (Table 2) are low, indicating that companies making IT investments have not been accompanied by good IT planning and strategic steps. The company has not put the IT strategy into an important component. Based on the high influence of IT strategies on the business value of IT and the low IT strategy that has been carried out, the business value of manufacturing companies in Central Java can still be improved by planning more intensive IT strategies.

Based on Table 4, the IT budget indicator has the highest item-total correlation, meaning that companies' regular budget will have an important contribution to IT strategy. Table 2 shows that respondents perceive the IT budget indicator to be very low. To optimize IT strategies in increasing business value, organizations need to prioritize IT budget allocation consistently.

\section{Interaction of IT strategy and IT usage}

The interaction of information technology strategies and the use of information technology have a positive influence on the value of information technology business. These results indicate that the IT strategy is able to increase the influence of IT use on IT business value. The increase in the influence of IT usage variables on the value of IT business due to the increase in IT strategy is greater than the effect of the IT usage variable itself. This means that the moderating influence of 
IT strategy variables is greater than the direct influence of IT use. Companies that plan for a better IT strategy than the capabilities of IT usage applications will be better and further enhance the company's business value. This is in line with the research of Yeh, et al. (2012), stating that the influence of the use of information technology on business value is highly dependent on the ability of the driver and its management.

Every business executive has a different purpose for using IT, so communication between IT executives and business executives needs to be done to understand each other's IT goals and capabilities. How to improve the suitability of an IT strategy with a business strategy is the mutual awareness of business goals and IT and the exchange of IT views for business executives and IT executives, or the involvement of business executives in planning information systems (Telbany \& Elragal, 2014)

The application of modern business systems such as electronic commerce, electronic business requires closer communication between business executives and IT executives for the successful implementation of IT investments in the future. Business executives must have the authority and control of IT according to their needs and conversely IT executives have greater authority in managing IT resources to be able to meet the needs of business executives. Business executives must realize that IT investments must be managed just like other capital investments, and more involved in IT investment decisions, directing the use of IT resources to support business strategies.

Companies will receive optimal benefits from IT investments when integrating business process infrastructure with IT infrastructure and adjusting business strategies to IT strategies (Chen et al., 2017). Placing the management of IT resources as important as the management of other company resources, the IT strategy can support business strategies (Alreemy et al., 2016). Companies having IT strategies are more in line with business strategies and have higher IT investment results, because IT investments are made more focused so as to improve IT capabilities.

\section{CONCLUSION}

The use of IT has a positive effect on business value. The wider the IT application is used, the greater the business value of IT obtained. The application of IT to large companies in Central Java is still at the level of the informational era after the transactional era can be exceeded. Executives realize that the application of IT at the level of communication and decision making is also very important to increase business value but empirically its implementation is still low.

The IT strategy moderates the influence of IT use on the business value of IT, even the effect of its interaction is greater than the effect of using IT. IT business value in large companies in Central Java still has a great opportunity to be improved, because IT strategy has a big influence on business value. However, it has not been followed by a strong IT strategy, especially the consistency of IT budget allocation, IT unit placement that is equivalent to business units, and the intensity of communication and coordination of IT units with business unit leaders.

Suggestions for manufacturing companies in Central Java are three folds. First, they need to shift the focus of IT investment towards communication and decision making. Second, managing IT 
resources is as important as other resources. Third, consistent and sustainable budget for IT investment needs to be allocated.

The limitation of this research is the relatively small participation of respondents and only applies to large manufacturing companies, so future research needs to use more effective survey methods and compare medium and large companies.

\section{ACKNOWLEDGEMENT}

We thank to the Central Java Industrial Service, which has appealed to companies to support the data needs of this research. Thanks also go to the executives of major manufacturing companies in Central Java who have participated in filling out the research questionnaire. We thank Prof. Vincent Didik Aryanto, Dean of the Faculty of Economics and Business at Dian Nuswantoro University and his staff who have supported this research. We also thank the reviewer team of the International Journal of Business and Society (IJBS) for giving corrections to the improvement of this article.We are grateful to the committee of the International Conference on Insuring Sustainable Business Strategy (ISBS), the Faculty of Economics and Business, Dian Nuswantoro University, which has suggested submitting articles to IJBS.

\section{REFERENCES}

Alaghehband, F. K., Rivard, S., Wu, S., \& Goyette, S. (2011). An assessment of the use of transaction cost theory in information technology outsourcing. The Journal of Strategic Information Systems, 20(2), 125-138.

Alreemy, Z., Chang, V., Walters, R., \& Wills, G. (2016). Critical success factors (CSFs) for information technology governance (ITG). International Journal of Information Management, 36(2), 907-916.

Amado, J. B., \& Walczuch, R. M. (2012). Information technology, the organizational capability of proactive corporate environmental strategy and firm performance: A resourcebased analysis. European Journal of Information Systems, 21(6), 664-679.

Aubert, B. A., \& Rivard S. (2016). “A Commentary on: The role of transaction cost economics in information technology outsourcing research: A meta-analysis of the choice of contract type", The Journal of Strategic Information Systems, 25(1), 64-67.

Bardhan, I., Krishnan, V., \& Lin, S. (2013). Business value of information technology: Testing the interaction effect of IT and R\&D on Tobin's Q. Information Systems Research, 24(4), $1147-1161$.

Bharadwaj, A. S., (2000). A resource-based perspective on information technology capability and firm performance: An empirical investigation. MIS Quarterly, 24(1), 169-196.

Bhatt, G. D., \& Emdad, A. F., (2010). An empirical examination of the relationship between information technology (IT) infrastructure, customer focus, and business advantages, Journal of Systems and Information Technology. 12(1), 4-16.

Boulesnane, S., \& Bouzidi, L. (2013). The mediating role of information technology in the decision-making context. Journal of Enterprise Information Management, 26(4), 387-399. 
Chen, Y., Wang, Y., Nevo, S., Benitez, J., \& Kou, G. (2017). Improving strategic flexibility with information technologies: Insights for firm performance in an emerging economy. Journal of Information Technology, 32(1), 10-25.

Choy, K. L., Gunasekaran, A., Lam, H. Y., Chow, K. H., Tsim, Y. C., Ng, T. W., Tse, Y. K., \& $\mathrm{Lu}, \mathrm{X}$. A. (2014). Impact of information technology on the performance of logistics industry: the case of Hong Kong and Pearl Delta region. Journal of the Operational Research Society, 65(6), 904-916.

Cui, T., Ye, H., Teo, H. H., \& Li, J. (2015). Information technology and open innovation: A strategic alignment perspective. Information \& Management, 52(3), 348-358.

Daulatkar, S., \& Sangle, P. S. (2015). Causality in information technology business value: A review. Business Process Management Journal, 21(3), 482-516.

Dimitrios, N. K., Sakas, D. P., \& Vlachos, D. S. (2013). The role of information systems in creating strategic leadership model. Procedia - Social and Behavioral Sciences, 73, 285 - 293.

Gorla, N., Somers T. M., \& Wong, B. (2010). Organizational impact of system quality, information quality, and service quality. The Journal of Strategic Information Systems, 19(3), 207228.

Grover, V., Teng, J. T. C., \& Fieder, K. D. (2002). Investigating the role of information technology in building buyer-supplier relationships. Journal of the Association for Information Systems, 3(1), 217-245.

Hamdani, N. A., \& Susilawati, W. (2018). Application of information system technology and learning organization to product innovation capability and its impact on business performance of leather tanning industry. International Journal of Engineering \& Technology, 7(2), 393-397.

Jiang, Y., \& Zhao, J. (2014). Co-creating business value of information technology. Industrial Management \& Data Systems, 114(1), 53- 69.

Kim, M. \& Chai, S. (2017). The impact of supplier innovativeness, information sharing and strategic sourcing on improving supply chain agility: Global supply chain perspective. International Journal of Production Economics, 187, 42-52.

Kite, G. (2012). The Impact of information technology outsourcing on productivity and output: new evidence from India. Procedia Economics and Finance 1, 239 - 248.

Kleis, L., Chwelos, P., Ramirez, R. V., \& Cockburn, I. (2012). Information technology and intangible output: The impact of IT investment on innovation productivity. Information Systems Research, 23(1), 42-59.

Kossai, M., \& Pigget, P. (2014). Adoption of information and communication technology and firm profitability: Empirical evidence from Tunisian SME. Journal of High Technology Management Research, 25(1), 9-12.

Lee, S., Xiang, J. Y., \& Kim, J. K. (2011). Information technology and productivity: Empirical evidence from the Chinese electronics industry. Information\& Management, 48(2-3), 7987.

Luftman, J., Lyytinen K., \& Zvi, T. (2017). Enhancing the measurement of information technology (IT) business alignment and its influence on company performance. Journal of Information Technology, 32(1), 26-46.

Mandal, P., \& Bagchi, K. (2016). Strategic role of information, knowledge and technology in manufacturing industry performance. Industrial Management \& Data Systems, 116(6), 1259-1278.

Melville N., Kraemer K. L., \& Gurbaxani V. (2004). Information technology and organization performance: An integrative model of IT business value. MIS quarterly, 28(2). 283-322. 
Mendonca, J. A. (2003). A model and sample case for teaching the business value of information technology. Journal of Information Technology Education, 2, 61-72.

Mooney J. G., Gurbaxani V., \& Kraemer K. L. (1996). A process oriented framework for assessing the business value of information technology. The DATA BASE for Advances in Information Systems, 27(2), 68-81.

Ogutu, S., Okello, J., \& Otieno, D. (2014). Impact of information and communication technologyBased market information services on smallholder farm input use and productivity: The case of Kenya, World Development, 64, 311-321.

Petter, S., DeLone, W., \& McLean, E. R. (2013). Information systems success: The quest for the independent variables. Journal of Management Information Systems, 29(4), 7-61.

Schermann, M., Dongus, K., Yetton, P. H., \& Krcmar, H. (2016). The role of transaction cost economics in information technology outsourcing research: A meta-analysis of the choice of contract type. The Journal of Strategic Information Systems, 25(1), 64-67.

Shao, B. B. M., \& Lin, W. T. (2001). Measuring the value of information technology in technical efficiency with stochastic production frontiers. Information and Software Technology 43(7), 447-456.

Smaczny, T. (2001). Is an alignment between business and information technology the appropriate paradigm to manage IT in today's organisations?. Management Decision 39(10), 797 802.

Suh Hanjun, Hillegersberg, J. V., Choi, J. \& Chung, S. (2013). Effects of strategic alignment on IS success: the mediation role of IS investment in Korea. Inf Technol Manag, 14, 7-27.

Tallon, P., Kraemer, K. L., \& Gurbaxani, V. (2000). Executives' perspections of the business value of information technology : A process-oriented approach. Journal of Management Information Systems, 16(4), 145-173.

Telbany, O., \& Elragal, A. (2014). Business-information systems strategies: A focus on misalignment, Procedia Technology, 16, 250-262.

Trainor, K. J., Rapp, A., Beitelspacher, L. S., \& Schillewaert, N. (2011). Integrating information technology and marketing: An examination of the drivers and outcomes of e-marketing capability. Industrial Marketing Management, 40(1), 162-174.

Vanpoucke, E., Vereecke, A., \& Muylle, S. (2017). Leveraging the impact of supply chan integration through information technology. International Journal of Operation \& Production Management, 37(4), 510-530.

Wang, E. T. G., Hu Han-fen, \& Hu Paul Jen-Hwa. (2013). Examining the role of information technology in cultivating firms' dynamic marketing capabilities. Information \& Management, 50, 336-343.

Yeh, C. H., Lee, G. G., \& Pai, J. C. (2012). How information system capability affects e-business information technology strategy implementation: An empirical study in Taiwan. Business Process Management Journal, 18(2), 197-218.

Zhang, M., McCullough, J., \& Wei R. Y. (2004). Effects of organisational structure and information technology capability on organisational effectiveness in emerging markets. Journal of the Academy of Business and Economics, 14(1), 1-23. 